\title{
Pela Necessária Reconstrução do Processo Civil Brasileiro no Caminho de um Processualismo Democrático-Constitucional
}

\section{Fernando Hoffmam}

Mestre e doutorando em Direito Público pela Universidade do Vale do Rio dos Sinos (Unisinos). Bolsista Proex/ Capes. Membro do Grupo de Pesquisa Estado e Constituição e da Rede Interinstitucional de Pesquisa Estado e Constituição, vinculado à Unisinos e ao CNPq. Professor- titular do curso de Direito da Universidade Regional Integrada do Alto Uruguai e das Missões (URI/Campus Santiago). Membro do Grupo de Pesquisa Direito, Justiça e Cidadania, vinculado à URI e ao CNPQ. Especialista em Direito: Temas Emergentes em Novas Tecnologias da Informação e Bacharel em Direito pelo Centro Universitário Franciscano (Unifra). ferdhoffa@yahoo.com.br

\section{Larissa Nunes Cavalheiro}

Mestre em Direito pela Universidade Federal de Santa Maria (UFSM). Professora-substituta do curso de Direito da Universidade Federal de Santa Maria (UFSM). Membro do Grupo de Pesquisa Direitos da Sociobiodiversidade, vinculado a UFSM. Especialista em Direito Público pela Escola Superior da Magistratura Federal (Esmafe/RS). Especialista em Educação Ambiental pela UFSM. Bacharel em Direito pelo Centro Universitário Franciscano (Unifra). Advogada. laranunes7@hotmail.com

\section{Resumo}

0 presente artigo inicia-se explanando sobre a crise de efetividade enfrentada pelo processo civil, uma vez que ainda se encontra impregnado pelas influências da jurisdictio romana e o racionalismo do Estado Liberal. Após, passa-se a abordar o papel da hermenêutica, na busca de um processo 
fático, preventivo e capaz de atender ao Estado Democrático de Direito, possibilitando uma decisão autêntica, ou seja, constitucionalmente adequada. Finaliza-se defendendo a necessidade de uma nova jurisdição, capaz de produzir respostas adequadas ao caso concreto e, não, respostas universalizantes dadas a priori.

Palavras-chave: Decisão jurídica. Fato. Hermenêutica. Jurisdição. Processo civil.

\title{
NECESSARY BY RECONSTRUCTION OF BRAZILIAN CIVIL PROCESS IN THE WAY OF A PROCESSUALISM CONSTITUTIONAL-DEMOCRACY
}

\begin{abstract}
This article begins by explaining effectiveness of the crisis faced by the civil process, since it is still permeated by the influences of roman jurisdictio and rationalism of the liberal state. After going to address the role of hermeneutics, the search process for a factual, proactive and able to meet the paradigm of a democratic state, providing an authentic decision, that is, constitutionally adequate. Ends up referring, the need for a new jurisdiction, capable of producing appropriate responses to the case, responses and not given a priori universalizing.
\end{abstract}

Keywords: Legal decision. Fact. Hermeneutics. Jurisdiction. Civil process.

\section{Sumário}

1 Introdução. 2 Tradição Romano-Canônica e Racionalismo: fantasmas que ainda habitam o imaginário jurídico brasileiro. 3 Processo e Hermenêutica: o desvelar do Processo Civil enquanto "ser" Constitucional. 40 Necessário Acontecer de um Processualismo Democrático-Constitucional no Brasil. 5 Conclusão. 6 Referências. 


\section{INTRODUÇÃO}

É inadmissível um processo civil que seja fonte de decisões descontextualizadas, indiferentes ao contexto social, sendo este o destinatário das intenções constitucionais do atual Estado Democrático de Direito. É deste fato que emanam os fundamentos do presente artigo, trazendo consigo raciocínios pertinentes, para descrever de forma clara a origem da arguida crise processual, assim como a contribuição da hermenêutica para a efetividade jurisdicional. Buscando o desvelar dessa mesma crise, bem como, apontar algumas possibilidades para além dela.

Inicia-se apontando para o Direito Romano, de onde deriva a autoridade da lei, excluindo com isso possíveis interpretações aprimoradas sobre ela. Assim, o Direito é apenas “dito” e nada mais é realizado para a solução de conflitos, e essa influência jurídica alcança a modernidade, configurando um Direito Processual de cunho declaratório, que permanece até os dias atuais. Como se não bastasse a referida influência romana, surge então a concepção racionalista, que vem contribuir para a noção de que a atividade jurisdicional é um modo apenas de pronunciar a lei, sem mais comprometimentos com a complexa realidade dos âmbitos social, político e econômico. Dessa forma, surge uma crise no processo civil, pois este, ainda marcado pelas referidas influências, deixa de realizar direitos por meio do processo.

Passada essa explanação, atenta-se para o uso da hermenêutica como instrumento de aproximação do processo civil ao neoconstitucionalismo, pois do modo interpretativo-compreensivo hermenêutico, vai o processo ao encontro dos fatos da vida, efetivando-o constitucionalmente. É a partir deste entendimento que se propõe uma reconfiguração do sistema processual civil brasileiro, trazendo para este a essência que se espera do Estado Democrático de Direito e, diante disso, se erguem as possibilidades de instaurar uma jurisdição constitucional(izada). 
Fechando as pretensões do presente artigo, enfatizam-se os ainda existentes traços do racionalismo e do Direito Romano no Direito Processual Civil. Desse contexto deriva a insistência por práticas decisórias dissociadas do modelo constitucional pós-moderno. Nesse sentido, emanam decisões mecânicas, descontextualizadas e afastadas da realidade dos fatos. Não há uma adequação constitucional ao caso concreto, ou seja, o que existe é uma reprodução simplista de respostas predeterminadas a uma decisão.

Associando a complexidade da sociedade, seus anseios e as intenções do Estado Democrático de Direito, é imprescindível uma releitura do modus operandi do Direito Processual Civil, e, para tanto, vem se mostrando a hermenêutica um mecanismo de contenção da crise, que há muito se instaurou no processo.

\section{TRADIÇÃO ROMANO-CANÔNICA E RACIONALISMO: fantasmas que ainda habitam o imaginário jurídico brasileiro}

O sistema processual civil brasileiro passa por uma crise latente de efetividade. Tal situação ocorre em primeiro lugar pela proximidade da jurisdição atual com a jurisdictio romana e, em segundo lugar, devido ao aprisionamento do processo civil ao racionalismo do Estado Liberal.

Nesta senda, cabe abordar primeiramente a tradição romano-canônica, tradição esta na qual encontram morada os países de tradição civilista - civil law -, ancorada sobretudo, no Direito Romano. O Direito Romano, no curso de sua história, encontra-se divido em três períodos: o do Direito Romano antigo ou pré-clássico (753 a.C até 149/126 a.C.), tido como um momento primitivo da história jurídica romana; o do Direito Clássico (149/126 a.C. até 305 d.C.), que tem origem com a Lei Aebutia, 
que substitui o processo das legis actiones pelo processo per formulas, findando no reinado de Diocleciano; e finalmente o denominado período pós-clássico, a partir do reinado de Justiniano (Saldanha, 2011).

Tal esclarecimento sobre a "evolução" do Direito Romano faz-se necessário por estar a concepção de jurisdição na modernidade - e ainda contemporaneamente - atrelada à jurisdictio romana do período imperial já ao fim do Império Romano e próximo do declínio do seu Direito - mais propriamente dito, ao período justiniano (Baptista da Silva, 2007).

Nesse momento ocorre a publicização do processo civil, deixando este de ter o caráter privado característico do Direito Romano clássico, e assim, passando a ser um instrumento de coerção estatal (Baptista da Silva, 2007). Dessa forma, começam a ser desenhados os contornos do que será a jurisdição no Estado Liberal, também vista como instrumento de poder do soberano.

Justiniano, nesse período edita seu Corpus Juris Civilis como uma compilação legislativa autoritária e totalmente refratária a possíveis interpretações de seu texto. Tal compilado normativo tem o condão de abstratamente apontar exaustivamente normas capazes por si sós de "dizer o Direito”, constituindo assim o único meio oficial a ser utilizado na solução de conflitos (Merryman, 2007).

Desta forma, fica claro que na modernidade apenas o procedimento da actio foi absorvido pela processualística - nesse momento histórico vista realmente como ciência processualística -, em que apenas declaravam-se direitos, cabendo ao praetor por meio dos interditos fazer valer o direito anteriormente declarado (Baptista da Silva, 2007).

Esta absorção do Direito Romano pelo Direito moderno se dá de forma gradual, pois a partir da queda do Império Romano, os invasores passam a aplicar noções de Direito Romano, no entanto mais rudimentares do que a teoria jurídica romana dos idos do Império. Desse modo, é 
ao final do século 11 que renasce o Direito Romano, mais precisamente em Bolonha (Itália), optando-se por uma retomada do Direito Romano justiniano. De acordo com Merryman, esta opção pelo Corpus Júris Civilis ocorre pela visão italiana de um Sacro Império Romano, em que Justiniano era visto como o Sacro Imperador (Merryman, 2007).

Desta maneira é que passando pelo medievo a influência jurídica romana chega à modernidade. Assim, quando da formação do Estado Liberal é forjada uma jurisdição de profundas raízes romanas, oriundas dos tempos findos imperiais e da codificação justiniana. Esta origem romana tardia traz ao Direito Processual moderno um caráter meramente declaratório - o que permanece até os dias atuais - devido à supressão dos interditos, que a serviço do pretor ao mesmo tempo que já delimitavam a decisão com base na verossimilhança, tinham o poder de, se necessário, impor à parte sanções pelo descumprimento da condenação (Isaia, 2012).

Assim, constrói-se um sistema jurisdicional centrado na norma que desobriga o magistrado de decidir, pois a este cabe apenas declarar o direito posto pelo soberano. Tal situação é agravada pela concepção racionalista que ganha o Direito - Processual sobretudo - nesta quadra da História. Nesse período pós-revolucionário ganham força as codificações que passam a vigorar como fonte primeira, se não única, do Direito.

A jurisdição moderno-racionalista assim é concebida dentro de um projeto político-econômico que necessita de uma estrutura capaz de garantir o seu desenvolvimento e sua concretude. Nesse caminho, é necessário um aparato jurídico-administrativo que corrobore com a consolidação de um sistema patrimonialista e redutor dos sentidos, ao sentido econômico-burguês. Por tal motivo, essa jurisdicionalidade nascente prende-se ao binômio certeza e segurança a partir de uma administração da justiça de caráter meramente formal que concede aos sujeitos jurídico-sociais - e 
especialmente econômicos - o poder de gerir o conflito com base em uma autonomia privatística calcada nas liberdades e direitos igualitariamente imaginados (Saldanha, 2011).

Trata-se de uma jurisdicionalidade que ainda hoje se percebe aferrada aos modelos tutelares concebidos na modernidade, o que na ordem social atual desassossega a sociabilidade, que em meio a outro tipo de conflituosidade tenta resolver-se no âmbito das mazelas de um sistema preso a uma racionalidade liberal-econômica agora repaginada - neoliberal-mercadológica. Sustenta-se o processo jurisdicional contemporâneo sobre os braços de uma artificialidade significativa que sustenta um modelo processual esquizofrênico diante da complexidade social atual, a qual ele não consegue abarcar (Hoffmam; Saldanha, 2014). Neste momento encontra-se instaurada uma crise de efetividade que perdura até hoje, no entanto, atualmente, agravada pelas modificações nas esferas política, social e econômica. Tais alterações no modo de vida redundam em um aumento de complexidade no que respeita aos conflitos de direito, bem como às relações jurídico-sociais.

É desta forma que o sistema processual civil em terrae brasilis segue baseado na ordinariedade, na cognição exauriente e nas cisões metafísicas da modernidade, tendo como valor máximo o encontro com a verdade absoluta alcançada apenas após percorrer-se inteiramente o caminho do processo (Baptista da Silva, 2006). Nesse sentido, o processo permanece sendo não mais que um método apto a alcançar tecnicamente uma efetividade artificialmente concebida por um sentido de imutabilidade significativa centrado na razão infalível do sujeito. O sentido vem da técnica e objetivamente é dado pela norma a partir de um processo de mera subsunção, o que possibilita a manutenção de um status quo liberal-burguês de desigualdades. Esse processo-jurisdicional moderno-liberal não se dá no/com o mundo prático, pois, se assim fosse, estaria exposto às contingências e não mais imune à mutabilidade das estruturas sociais. 
Logra-se construir uma processualística científico-tecnicista que possa artificialmente, em um processo de atribuição de significados centrado na razão, construir as soluções artificiais imaginadas de antemão pela classe dominante (Hidalgo, 2011).

Desse modo, a modernidade ilustra um quadro jurídico racional e artificialmente concebido, hermeticamente fechado e refratário às complexidades vividas mundanamente pelos sujeitos sociais. No Direito moderno não há espaço para a mutabilidade da vida em sociedade, há uma estratificação das práticas sociais, o que provoca o seu esvaziamento enquanto ordenadoras do jurídico. Nesse contexto, concebe-se mitologicamente a lei moderna como organizadora de toda a complexidade social, em que o indivíduo capitalista encontra morada segura para as suas demandas econômico-financeiras (Grossi, 2007).

Propriedade privada, contrato e mercado devem ser juridicamente garantidos, o que é permitido por uma atividade jurisdicional calcada na reprodução de imagens perfeitas de justiça - capitalista - que se mostram imutáveis às situações da vida. $\mathrm{O}$ sujeito centro do mundo, (re)projeta essas imagens perfeitas de justiça construindo um sentido de imutabilidade e sobrelevando a segurança jurídica - da justiça imaginária capitalista - à justiça materialmente considerada (Hidalgo, 2011).

Conforma-se um sistema que tem como pilar de sustentação o processo de conhecimento, por excelência ordinário e não mais que declaratório, impossibilitando, assim, a efetividade processual substancial a qual é exigência do paradigma do Estado Democrático de Direito. Paradigma este que tem por vocação a instituição de uma ordem constitucional substancial, que deve(ria) ter como elemento propulsor um processo não mais ordinarizado, mas sim constitucional, que desse guarida à jurisdição forte e interveniente, compatível com a posição de modificadora dos cenários político-sociais (Hommerding, 2007). 
Neste momento cabe tão somente uma jurisdição, qual seja, a jurisdição constitucional(izada) ${ }^{1}$ - deixando-se de lado a cisão jurisdição ordinária $\mathrm{X}$ jurisdição constitucional -; cabe a realização de direitos por meio do caminho processual, e não mais o abalroamento do social por discursos de poder dominantes dados a priori; e cabe, sobremodo, o abandono da busca incessante por verdades absolutas em troca da possibilidade de encontrar-se interpretativamente a resposta constitucionalmente adequada ao caso concreto (Isaia, 2010).

Logo, em meio a esta nova roupagem de paradigma estatal, bem como diante das modificações político-sociais que propiciaram o agigantamento da complexidade social em relação ao Direito, o processo jurisdicional contemplado na modernidade torna-se insuficiente. Nessa perspectiva, faz-se necessário um novo modelo jurisdicional, capaz de resolver conflitos transindividuais e tutelar direitos nunca antes imaginados pelo legislador, que jogam o Direito ao caos e ao risco da sociedade contemporânea, em que o hoje já pode ser tarde.

No que toca ao processo civil, este reajuste das práticas jurisdicionais dar-se-á a partir de um olhar hermenêutico lançado sobre o processo. Esta nova visão hermenêutica, permitirá a retomada de um Direito Processual do fato, (re)habitando o mundo-do-ser - Heidegger -, recolocando a processualística como uma ciência da vida e não das racionalidades matemáticas da modernidade. É o que se passa a tratar.

\footnotetext{
${ }^{1} \mathrm{O}$ uso da expressão jurisdição constitucionalizada em detrimento de jurisdição constitucional dá-se pela possibilidade de se entender "jurisdição constitucional” como um modelo jurisdicional diverso, ante uma jurisdição não constitucional, estando-se assim aprisionados a uma concepção metafísico-dualista. Já, ao empregar-se o termo "jurisdição constitucionalizada" tem-se o sentimento de que todo o espaço jurisdicional foi constitucionalizado, ou seja, que a Constituição passou a habitar as entranhas do sistema jurídico e, assim, também, do sistema de justiça, não cabendo em meio ao novo paradigma operar-se sob uma concepção dualista que divide a atividade jurisdicional em constitucional e ordinária (Hommerding, 2007).
} 


\section{PROCESSO E HERMENÊUTICA: o desvelar do Processo Civil enquanto "ser" Constitucional}

Heidegger traz a questão do ser, "ser" este que deve conhecer-se para conhecer - estar - (n)o seu mundo, bem como conhecer o mundo que o circunda para conhecer-se - acontecer - enquanto ser-aí - ser de um ente. Esta relação dialógica permite o desvelar do ser - ser-aí heideggeriano - de seu ente, reconfigurando desta forma a relação do ser - ser-aí - com o mundo que o circunda e consigo mesmo enquanto ser de um ente (Heidegger, 2006).

Por essa razão, será a partir da hermenêutica o repensar do processo civil em tempos de neoconstitucionalismo. A partir do modus interpretativo-compreensivo hermenêutico será o processo recolocado no seu lugar de ciência social, afeita às agruras mundanas. Assim, torna-se indissociável a relação hermenêutica-processo civil na busca pelo ser - constitucional - do ente - processo (Isaia, 2012).

Nesta senda, de pronto, processo é ciência de fatos - fatos da vida - que buscam ser compreendidos no interior do processo/procedimento. Esta compreensão, ao contrário do que nos foi legado pela modernidade, não se dá mecanicamente, metodologicamente, mas acontece a partir de algo que nos é dado - não plenipotenciariamente - ex ante. Logo, o fato deverá ser compreendido, e, em tempos de neoconstitucionalismo, esta compreensão sobremaneira deve ser a correta constitucionalmente. Assim, torna-se também indissociável a relação processo-constituição, que dará efetividade constitucional à prática processual do agora (Hommerding, 2007).

É evidente a roupagem predominantemente hermenêutica do Direito Processual. Processo se faz no mundo, no tempo, buscando sentidos por meio da compreensão hermenêutica - circular hermenêutica - dos fatos trazidos ao mundo processual - que, embora seja dimensão diversa, 
por óbvio se perfaz em determinado momento histórico-temporal (Nascimento; Hoffmam; Cavalheiro, 2010). Nestes novos tempos, passa - ou deve passar - a relação jurídico-processual a ser, além dela mesma, uma relação hermenêutico-processual de desvelamento ${ }^{2}$ do significado constitucional dos fatos - do ser constitucional do próprio processo - enquanto pertencentes sempre a sua historicidade. Com efeito:

O homem é dotado de historicidade desde sempre e é impossível separar este atributo do todo da existência humana. Nós tentamos qualquer coisa para fazê-lo e sempre batemos contra as paredes da historicidade. Não há nada "de fora" da historicidade. Há o sentido que já está construído, e sou nascido "para dentro" dele [...] (Stein, 2008, p. 37).

A relação hermenêutico-processual será, neste rumo, indissociável do fato, pois em tempos de pós-positivismo é inadmissível um processo civil de decisões descontextualizadas do seu próprio mundo - o seu conjunto fático-processual. Decisões não são dadas $a$ priori, não são

${ }^{2}$ Esse desvelamento dá-se a partir do "método" fenomenológico hermenêutico, que em verdade, não é método - e por isso, faz-se diferenciação utilizando-se a palavra método entre aspas, ao tratar-se do "método" fenomenológico hermenêutico e, sem as aspas ao trata-se do método como concebido na modernidade - mas sim modo de ser-no-mundo. A hermenêutica heideggeriana não pode ser vista como método na trilha das antigas hermenêuticas. Há uma crucial ruptura entre o paradigma hermenêutico heideggeriano e os anteriores. A partir do "método" fenomenológico-hermenêutico - não como método, mas como modo de ser-no-mundo - Heidegger desentranha a pergunta pelo "como" - do método -, ou seja, mesmo a partir do uso de um método, há uma "pergunta" - um questionar-se - que desde-já-sempre questiona o próprio método em seu caminho - em sua metódica - que, desse modo, perde a veste de certeza, visto que, interpelado pelo "como" anterior a si mesmo método. O método deixa de ser um "algo simplesmente dado" que leva a um fim adiantado nele próprio enquanto método/fórmula universal(izável) e, passa a ser "acontecimento" de um "acontecer" que vem compreendido mesmo anteriormente ao método. O "método" fenomenológico-hermenêutico não é meio de acessibilidade, mas sim desvelamento de ser-no-mundo em suas possibilidades, desvelamento do acessível em sua própria acessibilidade anterior a si mesmo. O "método" fenomenológico-hermenêutico é um "eterno"/“contínuo" reprojetar das possibilidades de ser-no-mundo, é um sempre angustiar-se (Oliveira, 2008, p. 36-42). 
descoladas do fato que as gerou, tampouco, podem ser universalizadas na resposta a todo e qualquer caso que "parecer" idêntico - o que nos parece descabido, pois fatos não ocorrem por atacado (Ramires, 2010). Com efeito:

Compreender, pois, é um processo de história efeitual, pois "uma hermenêutica adequada à coisa em questão deve mostrar a realidade da história na própria compreensão". É uma empresa infrutífera tentar decidir fora da historia, e isso envolve tanto a intenção de resolver universalmente todos os casos futuros, quanto a pretensão de decidir em uma individualidade absoluta e irrepetível. Toda a decisão judicial está inevitavelmente lançada no mundo histórico (Ramires, 2010, p. 91).

Desta forma é que se torna imprescindível que a esta hermenêutica da faticidade agregue-se o postulado da interpretação constitucionalmente adequada para o fato submetido a juízo. Em que pese estar-se, aí sim, originando-se um Direito Processual correspondente ao Estado Democrático de Direito (Isaia, 2010). Direito Processual este que confira efetividade à prestação jurisdicional, tornando-a capaz de concretizar e garantir os direitos postos pelo novo constitucionalismo. Assim, a construção processual será construção hermenêutico-factual, jogada no mundo e, por tal motivo, tornando possível a tarefa interpretativo-compreensiva enquanto categoria hermenêutica - como um existencial (Stein, 2008).

Nesse caminho de ruptura com o paradigma metafísico moderno, as categorias filosófico-metafísicas são substituídas em Heidegger pelos existenciais hermenêutico-mundanos. Há uma existencialidade das "coisas do mundo”, não há mais lugar para a entificação e a confusão do ser-aí/ dasein com os demais entes intramundanos. Em meio à analítica exis- 


\section{tencial os existenciais surgem na Filosofia hermenêutica ${ }^{3}$ como condição} de possibilidade para romper com o arsenal categorial metafisico-objetificante/subjetificante (Stein, 2008).

Neste momento alcança-se a efetividade jurisdicional a partir da questão factual, no entanto esta (re)visão da importância do fato ao Direito - ao processo - traz a reboque a importância da interpretação-compreensão autêntica deste mesmo fato. Fato é evento social, acontecido no

${ }^{3}$ Cabe aqui, algumas considerações quanto à hermenêutica heideggeriana - filosofia hermenêutica - e à hermenêutica gadameriana - hermenêutica filosófica. A hermenêutica como tratada a partir de Heidegger traz ares novos ao âmbito filosófico. Estes novos ares propiciam uma crítica contundente aos paradigmas filosóficos modernos, quais sejam, a subjetividade, o fundamento, e razão absoluta e, para além dessa crítica, tem por consequência trazer novas formas de expor os pressupostos filosóficos da modernidade, reordenando a ordem das coisas. A partir daí, e da fenomenologia hermenêutica, a hermenêutica ela mesma, não é - não pode mais ser - vista como mero método, mas sim, sendo um "já ser" histórico efetual, torna-se modo-de-ser interpretativo-compreensivo destinado a qualquer forma de conhecimento. "Com isso, a hermenêutica não significava um ataque à razão como o compreendiam os modernos, mas representava a dimensão da historicidade em que essa razão se apoiava, na medida em que sempre já se pressupunha a dimensão do compreender”. Em Heidegger a hermenêutica surge como adjetivo, que, no caso, designará a/uma filosofia hermenêutica, que, como lembra Ernildo Stein, não se tem registro na história da Filosofia anterior a Heidegger. Nesse caminho na obra de Heidegger não se encontrará, porém, a hermenêutica adjetivada como filosófica. O que leva Ernildo Stein a dizer que ao mesmo tempo Gadamer recua e avança em relação a Heidegger quanto a hermenêutica. Ao mesmo tempo que recua nas pretensões heideggerianas, avança no sentido de retirar da própria filosofia - hermenêutica - $o$ adjetivo filosófica. Assim, no que tal adjetivo a diferencia das demais hermenêuticas, também lhe confere maior amplitude. "Denominar a hermenêutica de filosófica dava a Gadamer duas liberdades. Em primeiro lugar, o autor poderia introduzir uma maneira de compreender diferente daquelas das ciências do espírito. Mas, de outro lado, Gadamer por assim dizer se libertara do uso estrito da hermenêutica, como aparecia em Heidegger, o que lhe permitia também modificar o seu conceito de compreensão”. E segue Ernildo Stein: “[...] a intenção de Heidegger era introduzir, além do nível do ente do outro nível, ligado ao ser, um terceiro nível que, através do ser-aí, conduzia a idéia da compreensão do ser. Desse modo, a fenomenologia tem, como hermenêutica da facticidade da existência, a tarefa de preparar uma nova compreensão do ser, a partir de um conceito de tempo repensado a partir da temporalidade e da historicidade [...]".

“[...] Em Verdade e Método, Gadamer afirma que acolheu o conceito de facticidade, mas, deixando de lado a questão transcendental, o aplicaria ao todo da cultura e da história. Portanto, se o conceito de compreensão em Heidegger visava a chegar ao problema do ser, no nível da transcendentalidade como a compreendia a analítica existencial, a compreensão em Gadamer é desenvolvida no contexto de um projeto que procura recuperar a historicidade da cultura e do mundo vivido" (Stein, 2011, p. 9-24). 
mundo, logo hermenêutico por natureza e, por assim ser, deve ocorrer sua compreensão hermeneuticamente. Deste modo, ganha notória importância a noção de círculo hermenêutico, pois intérprete e fato ali jogados construíram autenticamente a decisão - a resposta constitucionalmente correta (Streck, 2011a).

A decisão passa(rá) a ser sempre constitucional, pois assentada sobre os ditames da Lei Maior, seja no momento em que os direitos ali albergados são violados ou quando estes mesmos direitos sequer encontram-se materializados no âmago da sociedade. Para isso torna-se imprescindível que a decisão nesta quadra da História dê-se jogada no mundo, ou seja, que assim como o ser, seja ela também um existencial hermenêutico, que ela mesma tenha desvelado o seu "ser" (Streck, 2011a).

Por óbvio, quando compreendemos o fato, esta compreensão já está posta antes mesmo de "olharmos" aquele fato em si. O sentido do ser do fato - aquele fato - já vem com a pré-compreensão que no compreender é recompreendida. Assim, enquanto ser-no-mundo é que o intérprete compreenderá o fato em sua mundaneidade, estando intérprete, e fato a ser compreendido - interpretado - lançados a uma circularidade histórica (Stein, 2008).

Dessa maneira, apresenta-se este modus compreensivo circular como condição de possibilidade para o rompimento para com as velhas práticas interpretativas subsuntivo-dedutivas, pois aqui está o intérprete circundado pelos sentidos e suas possibilidades. $\mathrm{O}$ intérprete trabalha jogado no círculo hermenêutico enquanto significante e significado. Não está o intérprete solipsisticamente "dando" significados, nem recebendo plenipotenciariamente um significado pré-dado pelo texto, mas sim, enquanto "ser", significando um "algo" para daí, sim, dar significado a um outro "algo" a partir do mundo e não do nada (Streck, 2011b).Logo, 
[...] é possível concluir que, após passar por um processo contínuo de fusões ontológicas e reciprocamente determinadas entre o intérprete e $o$ aspecto normativo, probatório e argumentativo, a verdade cognitiva para a decisão "acontece" no interior do círculo hermenêutico (Marrafon, 2010, p. 169).

Para que seja completa esta guinada no modus operandi jurisdicional em terrae brasilis, porém, é necessário que se construa para além de um processo hermeneuticamente adequado, sobremodo o novo processualismo que traga em si a roupagem do novo paradigma. Para tanto urge a consubstanciação de um processualismo constitucional-democrático que garante efetividade processo-jurisdicional aos sujeitos jurídico-sociais. É o que se passa a tratar.

\section{O NECESSÁRIO ACONTECER DE UM PROCESSUALISMO DEMOCRÁTICO-CONSTITUCIONAL NO BRASIL}

Nesse passo, o Direito deve ser invadido por esse sentido pulsante de Constituição - de constituir a ação - a impulsionar o acontecer efetivo e completo do que é um verdadeiro Estado Democrático de Direito. Para tal, é o processo, mecanismo jurídico - não no sentido de, a serviço do Direito, ou do que seja, da economia - indispensável à consolidação do novo paradigma, bem como ao atendimento das complexidades referentes à concretude do(s) direito $(\mathrm{s})$.

Por assim dizer, o processo precisa desejar a Constituição enquanto instituidora de um novo processualismo que anda pelos caminhos por ela - Constituição - trilhados e que oferece aos sujeitos jurídico-sociais um espaço de concretização e desvelamento do Direito no caso concreto (Warat, 2000). O espaço-tempo processual nesse momento deve guardar relação direta com o caso concreto e com o seu devido desvelar. Rompe-se com o mundo instituído pela modernidade jurídica castradora do novo e 
percebe-se no processo - democrático-constitucionalizado - a possibilidade do novo a partir da facticidade, da existencialidade do fato da vida levado ao processo e, assim, levando o processo ao mundo (Stein, 2008).

O ambiente processual a ser construído deve levar a sério o Direito, e não metavalores (pós)moderno-(ir)racionalistas, como segurança jurídica, paz social, eficiência, fluxo, produtividade, etc. O processo instituído no seio do novo paradigma deve levar a sério o caso concreto, a mundaneidade do Direito materializada na facticidade, o que permite ao intérprete "acessar" a resposta correta do ponto de vista constitucional, no espaço-tempo necessário ao desvelar - hermenêutico - do caso concreto e à concretização e/ou garantia do(s) direito(s) posto(s) em jogo - jogo processual-constitucional (Borges Motta, 2012).

Se o Direito, nesse sentido deve pautar-se pela concretização da ordem constitucional em sua substância e total extensão - e realmente deve -, o processo/jurisdição deve estar apto a, por suas linhas, concretizar e garantir a efetividade jurídico-constitucional. Traça-se um perfil constitucional de processo abarcado pela, e que abarque a complexidade social contemporânea (Saldanha, 2010). Sob o signo do Estado Democrático de Direito requer-se uma participação do Judiciário - magistrado que se coadune com este novo paradigma. Logo, não deve haver espaços para que o magistrado atue irresponsavelmente jurisdicionando como bem entender ou a serviço de terceiros. Deve, sim, ser permitido ao magistrado interpretar a norma de acordo com o caso concreto, sempre no horizonte de sentido constitucional (Streck, 2011a).

A Constituição, assim, invade o processo e constrói um espaço-tempo processual humano-existencial, pautado pela ordenação de um verdadeiro Estado Democrático de Direito a partir dele mesmo, processo jurisdicional constitucional(izado). Esse processo é temporalmente mundano, jurisdicionalmente democrático, decisoriamente fático e, sobretudo, ordenado pelo acontecer do social. 
Para que isso ocorra, processo e Constituição devem ser compreendidos autenticamente inseridos na tradição do Estado Democrático de Direito e compreendendo o sentido - hermeneuticamente que isso representa. Desse modo nascerá um Direito Processual Civil constitucional(izado), em que seus institutos não mais serão compreendidos apartados do sentido de/da Constituição. Surge assim uma tradição autêntica de processo civil (Hommerding, 2007).

Para além da constitucionalização do processo que se defende aqui, deve ser construído um novo processualismo, o processualismo democrático-constitucional. Para isso, além de levar o Direito a sério, há que se levar também a democracia a sério e encará-la como um processo em aberto, plural e revigorante das práticas político-jurídico-sociais.

A democracia não pode ser vista como um local de conforto para o ambiente de desregulação que está posto. A democracia deve colocar-se como condição de possibilidade para a construção de um Direito autônomo em relação a metavalores, sejam sociais, políticos ou econômicos. Não há como se pensar um novo processo sem a consolidação de um regime jurídico-político substancialmente democrático.

Para tanto faz-se imprescindível compreender a democracia como um projeto em aberto que proporciona a constante mutação e reordenação do social. Frise-se que não é um projeto aberto ao mercado, mas "em aberto” pelas alternâncias do tecido vivo da sociedade. Não há modelo democrático pronto e acabado, há - ou deveria haver - um ambiente democrático em constante harmonia e anarquia ao mesmo tempo, assumindo para si a instituição do jurídico, do político e do social.

Nesse contexto, o processo civil deve ver-se inundado por esse sentimento - sentido - de mudança social impregnado pela democracia no acontecer político. Deve o processo, no entanto, passar por uma democratização de dupla-face: para além de democratização oriunda de uma maior acessibilidade dos sujeitos jurídico-sociais às esferas processo-judiciais 
- democratização exoprocessual -, deve também democratizar-se desde seus institutos, enquanto lugar de fala, e permitindo a fala dos sujeitos jurídico-sociais, no sentido da sociedade como um todo e não apenas das partes do processo - democratização endoprocessual.

Dar-se-á destaque no presente artigo a essa segunda forma/necessidade de democratização do processo. O processualismo contemporâneo deve ser visto como ambiente de diálogo democrático entre os coparticipantes, o que possibilita a construção de uma jurisdição substancialmente democrática, pois garante aos participantes do processo jurisdicional a efetiva movimentação em processo-procedimento.

Como salienta Francisco José Borges Motta, agir democraticamente em processo - jurisdição - significa permitir aos contraditores tomar parte da construção do provimento, não necessariamente um ajudando mutuamente o outro - opinião nossa -, mas sim ambos buscando dialogicamente a produção de uma resposta adequada ao caso - ao seu caso - e ao deslinde da controvérsia. “Essa ‘participação’ de que falamos transcende a tradicional 'bilateralidade da audiência' para se concretizar na efetiva garantia de influência da argumentação das partes na formação do conteúdo das decisões judiciais...” (Borges Motta, 2012).

O modelo de processo democrático-constitucional que se defende é um ambiente de contradição dialógica entre as partes. Configura-se em um espaço-tempo hermenêutico-discursivo de simetria participativa em que não há protagonista - o juiz - nem imobilidade do juiz perante as partes. Os atores do processo dialogam em posição de igualdade dentro do cenário jurisdicional, formando um contexto decisório hermenêutico-comparticipativo atravessado pela linguagem (Nunes, 2009).

Dessa forma a jurisdição reafirma o seu papel na arena político-social como um espaço-tempo propício ao habitar da democracia. Essa reafirmação democrática do ambiente jurisdicional dá substância ao fenômeno processual, o que conforma toda a prática judicativo-processual a 
agir em nome da Constituição, dos direitos humano-fundamentais-sociais, da ressignificação da esfera pública e, principalmente, do encontro hermenêutico-democrático do processo com a facticidade do caso concreto (Saldanha, 2011).

Nesse sentido, cabe referir que ao reafirmar-se democraticamente a jurisdição constitucionalizada reafirma-se esta enquanto espaço-tempo de participação cidadã. A sociedade, para além das partes em processo é - deve ser - chamada a cooperar na construção responsável das respostas em matérias de grande complexidade e valor extensivo ao todo comunitário-social.

Trilha-se o caminho rumo a um processualismo democrático-constitucional que renega os alicerces da modernidade e reconstrói-se no frescor dos ares democrático-constitucionais instituídos pela nova feição paradigmática. Há que se alertar, porém, que embora livre das amarras da modernidade, o processualismo contemporâneo, mesmo pretendido como democrático-constitucional, não pode ficar à deriva e sujeito à utilização de metavalores como significantes decisórios.

O que deve ficar claro é que no contexto atual não há Direito que não o democrático-constitucional e que, logo, não há processo que não democrático-constitucional. A atividade jurisdicional nessa quadra da História deve alcançar aos sujeitos jurídico-sociais para além da decisão consubstanciada no caso concreto, o ambiente de fala propício à democracia, os institutos processuais necessários a sua concretude, e instâncias de micropoder legitimadas democraticamente a dizer o Direito "a qualquer momento".

O processualismo democrático-constitucional que se defende garante a autonomia cooriginária do Direito, rompendo os laços da modernidade e ao mesmo tempo alcançando ao processo jurisdicional contemporâneo bases sólidas para que não fique abandonado ao mercado de fluxo e produtivismo, tornando-se processualismo mais do que moderno-racional, 
pós-moderno-irracional. Um processualismo democrático-constitucional como se concebe é sobretudo autêntico e, assim sendo, autêntica manifestação hermenêutico-democrático-participativa da sociedade em processo.

\section{CONCLUSÃO}

A crise de efetividade do processo civil vem há muito tempo pautada no racionalismo do Estado Liberal, assim como da tradição romano-canônica, desobrigando o magistrado de decidir, uma vez que o sistema jurisdicional apresenta-se pautado na norma, sendo apenas necessário declarar o Direito posto pelo soberano. É diante disso que a jurisdição não passa de mera função declaratória, sendo o juiz tão somente “a boca que pronuncia a lei”.

É do referido contexto, somado à complexidade social oriunda dos âmbitos político, social e econômico, que se dá o agravamento da crise, pois a atual complexidade da sociedade gera conflitos de direito também, tão complexos quanto os fatos sociais que os originam. Para tanto, deve a jurisdição mostrar-se constitucional(izada), abarcando os complexos anseios sociais, realizando os direitos por meio do processo, partindo daí o encontro interpretativo com a resposta constitucionalmente adequada ao caso concreto.

Para alterar e auxiliar a realização desse novo modus operandi, vem a hermenêutica como instrumento para efetuar o (re)pensar do processo civil em tempos de neoconstitucionalismo. O modo interpretativo-compreeensivo hermenêutico é que apresentará o processo ao status de ciência social, pois o fato será compreendido nos moldes do neoconstitucionalismo. A compreensão será constitucionalmente correta, logo, trará consigo a associação processo/Constituição, efetivando constitucionalmente a prática processual conforme os anseios sociais. 
Estando a relação hermenêutica-processo configurada, com o fato atrelado a ela, estarão as decisões contextualizadas no período pós-positivista característico do presente, demonstrando a realidade na própria compreensão, decidindo judicialmente no mundo histórico em que a sociedade se encontra. Quando o fato é submetido a juízo, para concretizar a pretensão em se adequar a reposta à Lei Maior, vem então a hermenêutica originar um Direito Processual afeito ao Estado Democrático de Direito. Dessa forma, rompe-se com as práticas subsuntivas-dedutivas, porque $o$ intérprete apresenta-se mergulhado em sentidos e possibilidades, mas, para tanto, deve afastar-se também da busca racional pela verdade unicamente trazida pelo texto normativo.

Deriva desse entendimento que as decisões jurídicas no tempo atual devem estar comprometidas com a complexidade social, sendo necessário abandonar discursos que tratem o caso concreto como "mais um" em meio a tantos semelhantes. Não abandonando essa postura, estará se configurando um problema hermenêutico, em que o magistrado faz uso de jurisprudências e doutrinas para fundamentar suas decisões. Essa cultura jurídica não passa de reproduções mecânicas, nas quais não se apreende os significados do fato social.

É no sentido da hermenêutica que se tem um afastamento do uso de sentidos predeterminados à decisão, compreendendo o contexto social e possibilitando a associação incindível da interpretação/aplicação/fundamentação. Assim, decide-se garantindo a substancialidade constitucional, ou seja, se garantem e concretizam direitos, conforme a essência do Estado Democrático de Direito.

\section{REFERÊNCIAS}

BAPTISTA DA SILVA, Ovídio A. Jurisdição e execução na tradição romano-canônica. Rio de Janeiro: Forense, 2007. 
. Processo e ideologia: o paradigma racionalista. Rio de Janeiro: Forense, 2006.

BORGES MOTTA, Francisco José. Levando O Direito A Sério: uma crítica hermenêutica ao protagonismo judicial. Porto Alegre: Livraria do Advogado, 2012. GROSSI, Paolo. Mitologias jurídicas da modernidade. Tradução Arno Dal Ri Júnior. Florianópolis: Fundação Boiteux, 2006.

HEIDEGGER, Martin. Ser e tempo. Petrópolis: Vozes, 2006.

HIDALGO, Daniela Boito Maurmann. Relação entre Direito Material e processo. Uma compreensão hermenêutica: compreensão e reflexos da afirmação da ação de direito material. Porto Alegre: Livraria do Advogado, 2011.

HOFFMAM, Fernando; SALDANHA, Jânia Maria Lopes. Da pós-modernidade processual: o hipermoderno e 0 antimoderno na caracterização do processualismo contemporâneo. In: Revista Direitos Fundamentais e Justiça, ano 8, n. 26, p. 136-159, jan./mar. 2014.

HOMMERDING, Adalberto Narciso. Fundamentos para uma compreensão hermenêutica do processo civil. Porto Alegre: Livraria do Advogado, 2007.

ISAIA, Cristiano Becker. Processo civil e hermenêutica: a crise do procedimento ordinário e o redesenhar da jurisdição processual civil pela sentença (democrática) liminar de mérito. Curitiba: Juruá, 2012.

ISAIA, Cristiano Becker. Processo civil, atuação judicial e hermenêutica filosófica: a metáfora do juiz instrutor e a busca por respostas corretas em direito. Faticidade e oralidade. Curitiba: Juruá, 2010.

MARRAFON, Marco Aurélio. O caráter complexo da decisão em matéria constitucional: discursos sobre a verdade, radicalização hermenêutica e fundação ética na práxis jurisdicional. Rio de Janeiro: Lumen Juris, 2010.

MERRYMAN, John Henry. La Tradición Jurídica Romano-Canónica. México: Fondo de Cultura Económica, 2007.

NASCIMENTO, Valéria Ribas do; HOFFMAM, Fernando; CAVALHEIRO, Larissa Nunes. Determinismo/positivismo versus indeterminismo/neoconstitucionalismo: observações sobre o tempo e o processo. Revista do Direito, Santa Cruz do Sul, n. 34, p. 50. jul./dez. 2010. Disponível em: $<$ http://online. unisc.br/seer/index.php/direito/article/viewFile/1659/1235>. 
NUNES, Dierle José Coelho. Processo jurisdicional democrático: uma análise crítica das reformas processuais. Curitiba: Juruá, 2009.

OLIVEIRA, Rafael Tomaz de. Decisão judicial e o conceito de princípio: a hermenêutica e a (in)determinação do Direito. Porto Alegre: Livraria do Advogado, 2008.

RAMIRES, Maurício. Crítica à aplicação de precedentes no Direito brasileiro. Porto Alegre: Livraria do Advogado, 2010.

SALDANHA, Jânia Maria Lopes. Substancialização e efetividade do Direito Processual Civil. A Sumariedade Material da Jurisdição: proposta de estabilização da tutela antecipada em relação ao projeto de novo CPC. Curitiba: Juruá, 2011.

A jurisdição partida ao meio: a (in)visível tensão entre eficiência e efetividade. In: STRECK, Lenio Luiz; MORAIS, José Luis Bolzan de (Orgs). Constituição, sistemas sociais e hermenêutica: anuário do programa de pós-graduação em Direito da Unisinos, n. 6. Porto Alegre: Livraria do Advogado, 2010. STEIN, Ernildo. Racionalidade e existência: o ambiente hermenêutico e as ciências humanas. Ijuí: Ed. Unijuí, 2008.

. Gadamer e a consumação da hermenêutica. In: STRECK, Lenio Luiz; STEIN, Ernildo (Orgs.). Hermenêtica e epistemologia: 50 anos de Verdade e Método. Porto Alegre: Livraria do Advogado, 2011.

STRECK, Lenio Luiz. Verdade e consenso: constituição, hermenêutica e teorias discursivas. Rio de Janeiro: Lumen Juris, 2011a.

. Hermenêutica jurídica $e(m)$ crise: uma exploração hermenêutica da construção do Direito. Porto Alegre: Livraria do Advogado, 2011b.

WARAT, Luis Alberto. A Ciência Jurídica e Seus Dois Maridos. Santa Cruz do Sul: EDUNISC, 2000.

Recebido em: 26/6/2015

Aprovado em: 27/1/2016 